\title{
Nitroso-R-salt as a sensitive spectrophotometric reagent for the determination of paracetamol in pharmaceutical preparations
}

\author{
Raghad Sinan* \\ Sadeem S. Abed* \\ Date of acceptance $19 / 11 / 2008$
}

\begin{abstract}
Nitroso-R-salt is proposed as a sensitive spectrophotometric reagent for the determination of paracetamol in aqueous solution. The method is based on the reaction of paracetamol with iron(III) and subsequent reaction with nitroso-R-salt to yield a green colored complex with maximum absorption at $720 \mathrm{~nm}$. Optimization of the experimental conditions was described. The calibration graph was linear in the concentration range of $0.1-2.0 \mu \mathrm{g} \mathrm{mL} \mathrm{m}^{-1}$ paracetamol with a molar absorptivity of $6.9 \times 10^{4} \mathrm{~L} \mathrm{~mol}^{-1} \mathrm{~cm}^{-1}$. The method was successfully applied to the determination of paracetamol in pharmaceutical preparations without any interference from common excipients. The method has been statistically evaluated with British Pharmacopoeia method and no statistical difference between methods was found at the $95 \%$ confidence level.
\end{abstract}

Key words: Paracetamol; Spectrophotometry; Nitroso-R-salt; Pharmaceutical preparations.

\section{Introduction}

Nitroso-R-salt is the disodium salt of $\alpha$-nitroso- $\beta$-naphthol disolfonic acid. This reagent was used for qualitative identification of ferrous ion and for copper and nickel ions at low $\mathrm{pH}[1]$.

Paracetamol (acetaminophen) has the chemical name N-(4hydroxyphenyl) acetamide. It is important and extensively used as antipyretic-analgesic drug [2].

Various methods have been reported for the determination of paracetamol in pharmaceutical preparations. These include spectrophotometry [3-7], polarography [8], micellar electrokinetic chromatography [9], flow injectionspectrofluorimetry [10], flow injection fourier-transform infrared spectrometry [11], flow injectionspectrophotometry $[12,13]$, first derivative spectrofluorimetry [14],

square-wave voltammetry [15], flow injection-biamperometry [16], highperformance thin-layer chromatography [17], and reversedphase capillary electrochromatography [18].

Most of spectrophotometric methods need either pre-hydrolysis step [19] or temperature and $\mathrm{pH}$ controls [20]. Therefore, development of a simple and sensitive spectrophotometric method seems to be desirable. The present paper describes a simple and sensitive spectrophotometric method for the evaluation of paracetamol in pharmaceutical preparations. The method is based on the reaction of paracetamol with iron(III) and subsequent reaction with nitroso-R-salt to yield a green colored complex. A comparative study of this method with *Department of Chemistry, College of Science, University of Baghdad, Baghdad Iraq 
the official method reported in pharmacopoeia was made. The present method offers the advantages of simplicity, no need for extraction or heating, in addition to higher sensitivity in comparison with some of the existing spectrophotometric methods.

\section{Materials and methods: Apparatus}

A Shimadzu UV-visible 260 digital double-beam recording spectrophotometer (Shimadzu, Kyoto, Japan) was used for all spectral and absorbance measurements with matched $1-\mathrm{cm}$ quartz cells.

\section{Reagents}

All chemicals used were of analytical reagent grade. Paracetamol standard material was provided from the State Company for Drug Industries and Medical Appliances (SDI), Samarra - Iraq

1- Paracetamol stock standard solution $1000 \mu \mathrm{g} \mathrm{mL}^{-1}$ was prepared by dissolving $0.1000 \mathrm{~g}$ of pure paracetamol in $5 \mathrm{ml}$ of ethanol and diluting to the marked with distilled water in $100 \mathrm{~mL}$ volumetric flask. Working standard solutions were prepared by suitable dilution of the stock standard solution.

2- Ferric sulfate solution $1 \mathrm{mM}$ was prepared by dissolving $0.0562 \mathrm{~g}$ of ferric sulfate in distilled water and diluting to the marked in $100 \mathrm{~mL}$ volumetric flask.

3- Nitroso-R-salt solution $10 \mathrm{mM}$ was prepared by dissolving $0.3773 \mathrm{~g}$ of nitroso-R-salt in distilled water and diluting to the marked in $100 \mathrm{~mL}$ volumetric flask.

\section{Pharmaceutical preparations of paracetamol}

Pharmaceutical preparations were obtained from commercial sources.
1- Paracetol tablets (SDI, Iraq): 500 mg paracetamol for each tablet.

2- Panadol Extra tablets (Smithkline Beecham, Ireland): $500 \mathrm{mg}$ paracetamol, $65 \mathrm{mg}$ caffeine for each tablet.

3- Panatol tablets (Global Pharma, UAE): $500 \mathrm{mg}$ paracetamol for each tablet.

4- Emidol tablets (Global Pharma, UAE): $500 \mathrm{mg}$ paracetamol for each tablet.

5- Kanagesic tablets (Kanawati Medical Products, Syria): $450 \mathrm{mg}$ paracetamol and $35 \mathrm{mg}$ orphenadrine citrate for each tablet.

6- Hayamol injections (Ibn Hayyan Pharmaceutical HOMS, Syria): 375 mg paracetamol for each injection $(5 \mathrm{~mL})$

\section{Calibration graph}

Aliquot of standard paracetamol solution $(2.5-50.0 \quad \mu \mathrm{g})$ was transferred into $25 \mathrm{~mL}$ calibrated flasks. To each flask, $1.5 \mathrm{~mL}$ of ferric sulfate solution $(1 \mathrm{mM})$, shake well and followed by $3 \mathrm{~mL}$ of nitrosoR-salt solution $(10 \mathrm{mM})$. The contents were diluted to the mark with distilled water and mixed; after $45 \mathrm{~min}$, the absorbance value at $\lambda_{\max } 720 \mathrm{~nm}$ was measured against a reagent blank and a calibration graph was constructed.

Procedure for the assay of pharmaceutical preparations

1- Tablets solution $\left(1000 \mu \mathrm{g} \mathrm{mL}^{-1}\right)$

The average tablet weight was calculated from the contents of 20 tablets that had been finely powdered and weighed. A portion of this powder, equivalent to $100 \mathrm{mg}$ of paracetamol, was accurately weighed, shaken with 5 $\mathrm{mL}$ of ethanol, diluted with distilled water in to a $100 \mathrm{~mL}$ volumetric flask and was filtered.

2- Injections solution $\left(1000 \mu \mathrm{g} \mathrm{mL}^{-1}\right)$

The contents of five injections were mixed. An aliquot corresponding to 
$100 \mathrm{mg}$ of paracetamol $(1.3 \mathrm{~mL})$ was shaken with $5 \mathrm{~mL}$ of ethanol and diluted to $100 \mathrm{~mL}$ with distilled water in a volumetric flask.

Further appropriate solutions of pharamaceutical preparations were made by using simple dilution with distilled water. Two different concentrations of each solution of pharmaceutical preparations were analyzed in five replicate using the above procedure.

\section{Results and discussion}

The proposed spectrophotometric method for the determination of paracetamol is based on the oxidation reaction of paracetamol with iron(III) and subsequent chelation of iron(II) with nitroso-R-salt to form a green colored product.

\section{Spectral characteristics}

A green product is formed when paracetamol was allowed to react with iron(III) salts and subsequent reaction of iron(II) produced with nitroso-Rsalt. The soluble colored complex has a maximum absorption at $720 \mathrm{~nm}$ as shown in Fig. (1)

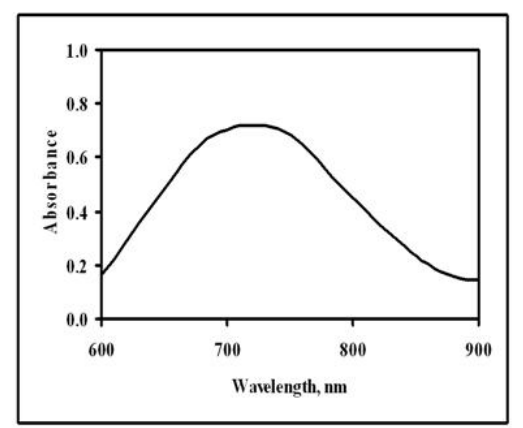

Fig. (1): Absorption spectrum of complex of nitroso-R-salt with iron(II) which produced from oxidation reaction of paracetamol $\left(1.5 \mu \mathrm{g} \mathrm{mL}^{-1}\right)$ with iron(III)

\section{Optimum conditions for complex} formation

In order to establish the optimum conditions necessary for a rapid and quantitative formation of the colored product with maximum stability and sensitivity, the investigators measured the absorbance of a series of solutions by varying one and fixing the other parameters at $720 \mathrm{~nm}$. It was found that a $1 \mathrm{mM}$ solution of ferric sulfate in the range $\quad 0.5-4.0 \mathrm{~mL}$ and a 10 $\mathrm{mM}$ solution of nitroso-R-salt in the range $0.5-5.0 \mathrm{~mL}$ were necessary to achieve a maximum color intensity of the product. Fig. (2) shows that $1.5 \mathrm{~mL}$ of ferric sulfate solution $(1 \mathrm{mM})$ and $3 \mathrm{~mL}$ of nitroso-R-salt solution (10 $\mathrm{mM}$ ) were enough to obtain the maximum absorbance. Therefore, $1.5 \mathrm{~mL}$ of ferric sulfate and $3 \mathrm{~mL}$ of nitroso-R-salt were recommended for all measurements.

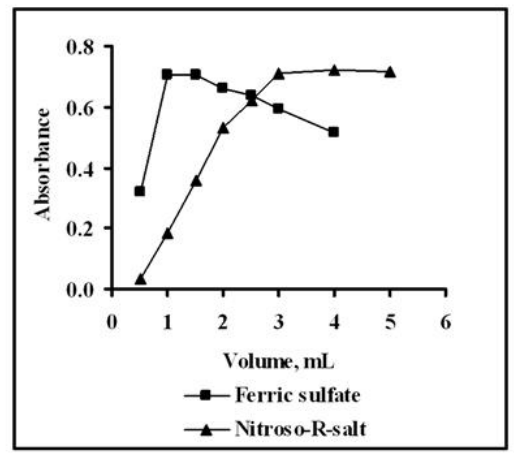

Fig. (2): Optimum conditions for determination of paracetamol

The reaction between paracetamol and iron(III) in the presence of nitroso$\mathrm{R}$-salt was found to be instantaneous. However, the reaction is complete within $45 \mathrm{~min}$ at room temperature (25 ${ }^{\circ} \mathrm{C}$ ).

The effect of temperature on the colored product was studied at 5, 25 and $45{ }^{\circ} \mathrm{C}$ and the results obtained indicated that the color was stable for at least $120 \mathrm{~min}$ at $25^{\circ} \mathrm{C}$ and was used in the recommended procedure. 


\section{Reaction mechanism}

Paracetamol reduces iron(III) salts in aqueous medium to form iron(II) salts, which subsequently chelate with nitroso-R-salt to form a green colored product as given in the following equations $[1,21]$

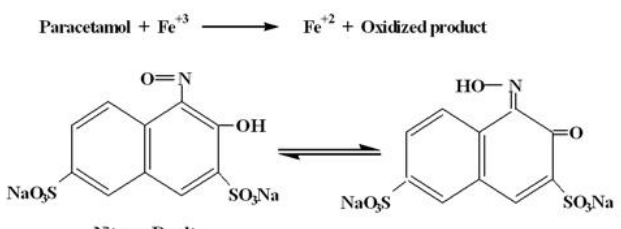

Nitroso-R-salt

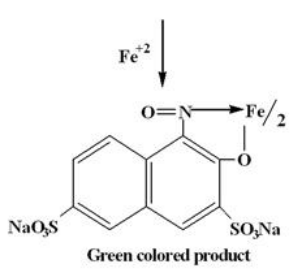

\section{Analytical parameters}

Employing the conditions described under analytical procedure, a linear calibration graph [Fig. (3)] for paracetamol was obtained. It shows that Beer's law was obeyed in the range given in Table (1). The analytical and regression parameters [22] of proposed spectrophotometric method are compiled in Table (1), and demonstrate the highly sensitivity of the method.

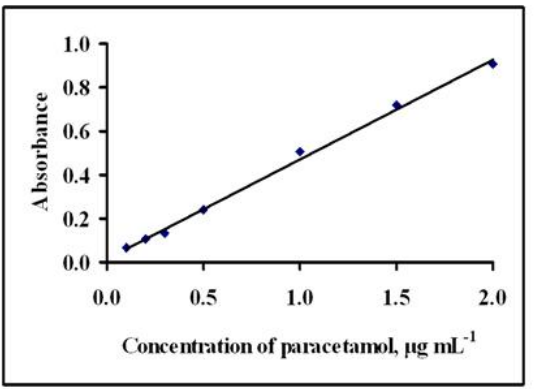

Fig. (3): Calibration graph for paracetamol
Table (1): Analytical and regression parameters of proposed method Accuracy and precision

\begin{tabular}{|c|c|}
\hline Parameter & Value \\
\hline$\lambda_{\max }, \mathrm{nm}$ & 720 \\
\hline Beer's law limits $\left(\mu \mathrm{g} \mathrm{mL}^{-1}\right)$ & $0.1-2$ \\
\hline $\begin{array}{l}\text { Regression equation } \\
\mathrm{y}=\mathbf{a}+\mathbf{b} \mathbf{x} ; \mathrm{y}=\mathrm{absorbance}, \\
\mathrm{x}=\text { concentration }\left(\mu \mathrm{g} \mathrm{mL}^{-1}\right)\end{array}$ & $\begin{array}{c}y=0.0165+ \\
0.4566 x\end{array}$ \\
\hline Correlation coefficient, $r$ & 0.9980 \\
\hline Correlation of determination, $\mathrm{r}^{2}$ & 0.9960 \\
\hline Intercept, a & 0.0165 \\
\hline Slope, b (mL $\left.\mu \mathrm{g}^{-1}\right)$ & 0.4566 \\
\hline Standard deviation of the residuals, $S_{\mathrm{yX}}$ & 0.0230 \\
\hline Standard deviation of the intercept, $S_{a}$ & 0.0135 \\
\hline Standard deviation of the slope, $S_{b}$ & 0.0130 \\
\hline Molar absorptivity, $\varepsilon\left(\mathrm{L} \mathrm{mol}^{-1} \mathrm{~cm}^{-1}\right)$ & $6.902 \times 10^{4}$ \\
\hline $\begin{array}{l}\text { Sandell's sensitivity, S } \quad\left(\mathrm{ng} \quad \mathrm{cm}^{-2}\right) \\
\text { per } 0.001 \text { absorbance unit }\end{array}$ & 2.1902 \\
\hline $\begin{array}{l}\text { Limit of detection, LOD }\left(\mu \mathrm{g} \mathrm{mL}^{-1}\right) \mathrm{LOD} \\
=3 \mathrm{~S}_{\mathrm{yx}} / \mathrm{b}\end{array}$ & 0.1513 \\
\hline $\begin{array}{l}\text { Limit of quantification, } \operatorname{LOQ}\left(\mu \mathrm{g} \mathrm{mL}^{-1}\right) \\
\operatorname{LOQ}=10 \mathrm{~S}_{\mathrm{v}_{\mathrm{x}}} / \mathrm{b}\end{array}$ & 0.5044 \\
\hline
\end{tabular}

To determine the accuracy and precision of the method, pure paracetamol solution was determined at two different concentrations. The results shown in Table (2), indicate that a satisfactory precision and accuracy could be obtained with the proposed method.

\section{Interference}

To test the efficiency and selectivity of the proposed analytical method to pharmaceutical preparations, a systematic study under the optimum experimental conditions was made for the effect of additives and excipients such as lactose, talc, starch, magnesium stearate and polyvinylpirrolidone (PVP) that are usually present in dosage forms. The criterion of interference was an error of not more than $\pm 1 \%$ in the absorbance. In this study, a wide range of concentrations was used in which the determination of the $2 \mu \mathrm{g} \mathrm{mL}^{-1}$ level of a drug was performed. Experimental results showed that there was no interference from additives or 
excipients for the examined method up to 10-fold excess as shown in Table (3)

Table (2): Accuracy and precision of the proposed method

\begin{tabular}{|c|c|c|c|c|}
\hline \multicolumn{2}{|c|}{$\begin{array}{c}\text { Concentration of } \\
\text { paracetamol }\left(\mu \mathrm{gL} \mathrm{m}^{-1}\right)\end{array}$} & \multirow{2}{*}{$\begin{array}{c}\text { Erel., } \\
\%\end{array}$} & \multirow{2}{*}{$\begin{array}{c}\text { Rec., } \\
\%\end{array}$} & \multirow{2}{*}{$\begin{array}{c}\text { RSD, } \\
\%\end{array}$} \\
\hline Taken & Found ${ }^{*}$ & & & \\
\hline 0.3000 & 0.2992 & -0.267 & 99.733 & 1.273 \\
\hline 1.0000 & 1.0153 & +1.530 & 101.530 & 0.807 \\
\hline \multicolumn{5}{|c|}{$\begin{array}{l}\text { Erel. is relative error. Rec. is recovery. } \\
\text { RSD is relative standard deviation. } \\
\text { " Mean value of five determinations. }\end{array}$} \\
\hline
\end{tabular}

Table (3): Determination of $2 \mu \mathrm{g} \mathrm{mL}^{-1}$ of paracetamol in the presence of excipients

\begin{tabular}{|c|c|c|c|c|}
\hline \multirow[t]{2}{*}{$\begin{array}{l}\text { Excipient, } \\
20 \underset{1}{\mu} \mathrm{mL}\end{array}$} & $\begin{array}{c}\text { Conc. of } \\
\text { paracet-amol, } \mu \mathrm{g} \\
\mathrm{mL}^{-1}\end{array}$ & \multirow[t]{2}{*}{$\begin{array}{l}\text { Erel., } \\
\%\end{array}$} & \multirow[t]{2}{*}{$\begin{array}{l}\text { Rec., } \\
\%\end{array}$} & \multirow[t]{2}{*}{$\begin{array}{c}\text { RSD, } \\
\%\end{array}$} \\
\hline & Found ${ }^{*}$ & & & \\
\hline Lactose & 2.0037 & +0.185 & 100.185 & 0.612 \\
\hline Starch & 1.9920 & -0.400 & 99.600 & 0.251 \\
\hline Talc & 2.0191 & +0.955 & 100.955 & 0.337 \\
\hline $\begin{array}{c}\mathrm{Mg} \\
\text { stearate }\end{array}$ & 1.9963 & -0.185 & 99.815 & 0.427 \\
\hline PVP & 2.0005 & +0.025 & 100.025 & 0.221 \\
\hline
\end{tabular}

\section{Analytical applications}

The proposed method was applied successfully to the determination of paracetamol in pharmaceutical preparations [Table (4)]. The results were compared statistically using Student's t-test for accuracy, and a variance ratio F-test for precision [22] with the official method [23] at the $95 \%$ confidence level [Table (5)]. The results showed that the t- and $\mathrm{F}$-values were less than the theoretical value, indicating there was no significant difference between both methods in accuracy, but the proposed method was more precise than the official method. Consequently, we advise to adopt the proposed method in routine analysis and for quality control purposes for paracetamol and related pharmaceutical preparations

\section{Conclusion}

The proposed method is found to be economical, simple, fairly and highly sensitive than other spectrophotometric methods [Table (6)]. It has the advantage of being accurate, does not require the removal of excipients, temperature control, $\mathrm{pH}$ control, solvent extraction step and prehydrolysis step. The statistical parameters and recovery study data clearly indicate the reproducibility and accuracy of the proposed method. It can be applied successfully to different pharmaceutical preparations

\begin{tabular}{|c|c|c|c|c|c|}
\hline \multirow{3}{*}{\multicolumn{2}{|c|}{$\begin{array}{l}\text { Table (4): } \\
\text { paracetamol } \\
\text { preparations } \\
\text { method }\end{array}$}} & \multicolumn{3}{|c|}{ Determination } & \\
\hline & & in & nha & 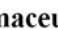 & $\mathbf{C}$ \\
\hline & & Ising & the & & sed \\
\hline \multirow[t]{2}{*}{$\begin{array}{c}\text { Pharmaceutical } \\
\text { Preparation }\end{array}$} & \multicolumn{2}{|c|}{$\begin{array}{c}\text { Concentration of } \\
\text { paracetamol }(\mu \mathrm{g} \\
\left.\mathrm{mL}^{-1}\right)\end{array}$} & \multirow[t]{2}{*}{$\begin{array}{l}\text { Erel., } \\
\%\end{array}$} & \multirow[t]{2}{*}{$\begin{array}{l}\text { Rec., } \\
\%\end{array}$} & \multirow[t]{2}{*}{$\begin{array}{l}\text { RSD, } \\
\%\end{array}$} \\
\hline & Taken & Found $^{*}$ & & & \\
\hline \multirow{2}{*}{$\begin{array}{c}\text { Paracetol } \\
\text { tablets }\end{array}$} & 0.5000 & 0.4925 & -1.500 & 98.500 & 0.563 \\
\hline & 1.5000 & 1.4930 & -0.467 & 99.533 & 0.269 \\
\hline \multirow{2}{*}{$\begin{array}{c}\text { Panadol Extra } \\
\text { tablets }\end{array}$} & 0.5000 & 0.4957 & -0.860 & 99.140 & 0.204 \\
\hline & 1.5000 & 1.5021 & +0.140 & 100.140 & 0.126 \\
\hline \multirow{2}{*}{$\begin{array}{l}\text { Panatol } \\
\text { tablets }\end{array}$} & 0.5000 & 0.4882 & -2.360 & 97.640 & 1.570 \\
\hline & 1.5000 & 1.5193 & +1.287 & 101.287 & 0.226 \\
\hline \multirow{2}{*}{$\begin{array}{l}\text { Emidol } \\
\text { tablets }\end{array}$} & 0.5000 & 0.4877 & -2.460 & 97.540 & 1.380 \\
\hline & 1.5000 & 1.5321 & +2.140 & 102.140 & 0.350 \\
\hline \multirow{2}{*}{$\begin{array}{c}\text { Kanagesic } \\
\text { tablets }\end{array}$} & 0.5000 & 0.5005 & +0.100 & 100.100 & 0.505 \\
\hline & 1.5000 & 1.5160 & +1.067 & 101.067 & 0.351 \\
\hline \multirow{2}{*}{$\begin{array}{l}\text { Hayamol } \\
\text { injections }\end{array}$} & 0.5000 & 0.4979 & -0.420 & 99.580 & 0.426 \\
\hline & 1.5000 & 1.5021 & +0.140 & 100.140 & 0.370 \\
\hline
\end{tabular}


Table (5): The comparison of the proposed method with standard official method using

\begin{tabular}{|c|c|c|c|c|c|c|c|}
\hline \multirow[b]{2}{*}{ Pharmaceutical preparation } & \multicolumn{2}{|c|}{ Proposed method } & \multicolumn{2}{|c|}{ Official method } & \multirow[b]{2}{*}{$\mathbf{s}$} & \multicolumn{2}{|c|}{ Value } \\
\hline & $\begin{array}{c}\text { Rec. } \%{ }^{*} \\
\left(x_{i}\right)_{1}\end{array}$ & $\left(\mathbf{x}_{i}-\overline{\mathbf{x}}\right)_{1}^{2}$ & $\begin{array}{c}\text { Rec. } \%{ }^{*} \\
\left(x_{i}\right)_{2}\end{array}$ & $\left(\mathbf{x}_{\mathrm{i}}-\overline{\mathbf{x}}\right)_{2}^{2}$ & & $\begin{array}{c}\mathrm{t} \\
\text { (theor. }\end{array}$ & $\begin{array}{c}\mathrm{F} \\
\text { (theor.) }\end{array}$ \\
\hline Paracetamol pure & 99.757 & 0.0004 & 100.000 & 0.3446 & \multirow{7}{*}{1.482} & \multirow{7}{*}{$\begin{array}{l}0.409 \\
(2.18)\end{array}$} & \multirow{7}{*}{$\begin{array}{c}2.266 \\
(4.284)\end{array}$} \\
\hline Paracetol tablets & 99.017 & 0.5184 & 98.881 & 0.2830 & & & \\
\hline Panadol Extra tablets & 99.640 & 0.0094 & 100.726 & 1.7240 & & & \\
\hline Panatol tablets & 99.464 & 0.0745 & 99.025 & 0.1505 & & & \\
\hline Emidol tablets & 99.840 & 0.0106 & 99.242 & 0.0292 & & & \\
\hline Kanagesic tablets & 100.584 & 0.7174 & 98.700 & 0.5084 & & & \\
\hline Hayamol injections & 99.860 & 0.0151 & 99.314 & 0.0098 & & & \\
\hline & $\begin{array}{l}\overline{\mathrm{X}}_{1}= \\
99.737\end{array}$ & $\begin{array}{c}\Sigma= \\
1.3458\end{array}$ & $\begin{array}{l}\bar{x}_{2}= \\
99.413\end{array}$ & $\begin{array}{l}\Sigma= \\
3.0495\end{array}$ & \multicolumn{2}{|c|}{$\left(\mathrm{n}_{1}+\mathrm{n}_{2}-2\right)=12$} & $\begin{array}{l}\left(\mathrm{n}_{1}-1\right)=6 \\
\left(\mathrm{n}_{2}-1\right)=6\end{array}$ \\
\hline
\end{tabular}

Table (6): Comparison of the proposed method with other spectrophotometric methods

\begin{tabular}{|c|c|c|c|c|c|}
\hline Reagents & $\lambda_{\max }$ & $\begin{array}{c}\text { Linear } \\
\text { range, } \\
\mu \mathrm{g} \mathrm{mL}^{-1}\end{array}$ & $\varepsilon, \mathbf{L} \mathbf{~ m o l}^{-1} \mathrm{~cm}^{-1}$ & Remarks & Ref. \\
\hline $\mathrm{HNO}_{3}+\mathrm{H}_{2} \mathrm{SO}_{4}$ & 355 & $\begin{array}{c}(0.2-1) \times \\
10^{3} \\
\end{array}$ & $4.747 \times 10^{3}$ & $\begin{array}{c}\text { Treated with acetone and } \mathrm{KOH} \\
\text { solution }\end{array}$ & 24 \\
\hline Cerium(IV) sulfate in $5 \mathrm{M} \mathrm{H}_{2} \mathrm{SO}_{4}$ & 410 & $30-160$ & $8.112 \times 10^{2}$ & $\begin{array}{l}\text { Required heating at } 80^{\circ} \mathrm{C} \text { for } \\
\qquad 90 \mathrm{~min}\end{array}$ & 25 \\
\hline Ammonium molybdate & 670 & $0.1-6$ & $2.600 \times 10^{4}$ & $\begin{array}{l}\text { Required strongly acidic } \\
\text { medium }\end{array}$ & 26 \\
\hline $\begin{array}{c}\text { Sodium 1,2-naphthoquinone-4-sulfonate and } \\
\text { cetyltrimethyl ammonium bromide }\end{array}$ & 570 & $1-20$ & $1.118 \times 10^{4}$ & $\begin{array}{c}\text { Required pre-hydrolysis of } \\
\text { paracetamol }\end{array}$ & 27 \\
\hline $\mathrm{o}-\mathrm{Cresol}+\mathrm{NaIO}_{4}+$ ammonium buffer $(\mathrm{pH} 10)$ & 612 & $2-44$ & $7.024 \times 10^{3}$ & Time consuming ( $50 \mathrm{~min})$ & 28 \\
\hline $\mathrm{NaNO}_{2}+\mathrm{HCl}$ & 430 & $180-300$ & $1.038 \times 10^{4}$ & $\begin{array}{l}\text { Treated with } \mathrm{NaOH} \text { solution in } \\
\text { flow injection system }\end{array}$ & 29 \\
\hline $\begin{array}{l}\text { Fe(III) + 1, 10-phenanthroline + acetate buffer } \\
\qquad(\mathrm{pH} 4.5)\end{array}$ & 510 & $0.5-10$ & $3.779 \times 10^{4}$ & Required heating at $60^{\circ} \mathrm{C}$ & 20 \\
\hline $\mathrm{Fe}(\mathrm{III})+$ nitroso-R-salt & 720 & $0.1-2$ & $6.902 \times 10^{4}$ & $\begin{array}{l}\text { Most sensitive, rapid and a } \\
\text { facile work }\end{array}$ & $\begin{array}{c}\text { Proposed } \\
\text { method }\end{array}$ \\
\hline
\end{tabular}

\section{References}

1.Fritz, F. and Vinzenz, A., 1972. 6th ed., Spot Tests in Inorganic Analysis. Elsevier Publishing Company, Amsterdam, pp. 669

2.The Merck Index on CD-ROM. 2000. 12th ed., Whitehouse Station, NJ, USA.

3.Romero, J. S. E., Rodriguez, L. A., Alvarezcoque, M. C. G. and Ramisramos, G., 1994. Spectrophotometric determination of phenols by coupling with diazotized 2,4,6-trimethylaniline in a micellar medium. Analyst. 119 (6): 13811386.

4.Erk, N. and Onur, F., 1997. Simultaneous determination of analgine and paracetamol in tablets by spectrophotometric methods. Anal. Lett. 30 (6): 1201-1210.
5.Mohamed, F. A., Abdallah, M. A. and Shammat, S. M., 1997. Selective spectrophotometric determination of p-aminophenol and acetaminophen. Talanta. 44 (1): 61-68.

6. Nogowska, M., Muszalska, I. and Zajac, M., 1999. Simultaneous spectrophotometric determination of acetylsalicylic acid, paracetamol and caffeine in pharmaceutical preparations. Chem. Anal. 44 (6): 1041-1048.

7.Sena, M. M. and Poppi, R. J., 2004. $\mathrm{N}$-way PLS applied to simultaneous spectrophotometric determination of acetylsalicylic acid, paracetamol and caffeine. J. Pharm. Biomed. Anal. 34 (1): 27-34.

8.Walash, M. I., Elbrashy, A. M. and Sultan, M. A., 1994. Polarographic behaviour and determination of 
paracetamol and salicylamide after treatment with nitrous acid. Microchim. Acta. 113 (1-2): 113124.

9.Boonkerd, S., Lauwers, M., Detaevernier, M. R. and Michotte, Y., 1995. Separation and simultaneous determination of the components in an analgesic tablet formulation by micellar electrokinetic chromatography. J. Chromatogr. 695 (1): 97-102

10. Pulgarin, J. A. M. and Bermejo, L. F. G., 1996. Flow-injection stopped-flow spectrofluorimetric kinetic determination of paracetamol based on its oxidation reaction by hexacyanoferrate(III). Anal. Chim. Acta. 333 (1-2): 5969.

11. Bouhsain, Z., Garrigues, S., Moralesrubio, A. and Delaguardia, M., 1996. Flow injection fouriertransform infrared spectrometric determination of paracetamol in pharmaceuticals. Analyst. 121 (5): 635-639.

12. Bouhsain, Z., Garrigues, S. and Delaguardia, M., 1996. Flow injection spectrophotometric determination of paracetamol in pharmaceuticals by means of online microwave-assisted hydrolysis and reaction with 8hydroxyquinoline (8-quinolinol). Anal. Chim. Acta. 330 (1): 59-69.

13. Criado, A., Cardenas, S., Gallego, M. and Valcarcel, M., 2000. Continuous flow spectrophotometric determination of paracetamol in pharmaceuticals following continuous microwave assisted alkaline hydrolysis. Talanta. 53 (2): 417-423.

14. Murillo, J. A. and Garcia, L. F., 1996. Application of first derivative fluorescence spectrometry to the simultaneous determination of paracetamol and salicylamide in pharmaceuticals. Anal. Lett. 29 (3): 423-438.

15. Zen, J. M. and Ting, Y. S., 1997. Simultaneous determination of caffeine and acetaminophen in drug formulations by square-wave voltammetry using a chemically modified electrode. Anal. Chim. Acta. 342 (2-3): 175-180.

16. Danet, A. F., David, V. and David, I., 1998. Acetaminophen determination by flow injection analysis with biamperometric detection. Rev. Roum. Chim. 43 (9): 811-816.

17. Argekar, A. P. and Sawant J. G., 1999. Simultaneous determination of paracetamol and mefenamic acid in tablets by HPTLC. JPC-J. Planar Chromatogr.-Mod. TLC. 12 (5): 361-364.

18. Pucci, V., Mandrioli, R., Raggi, M. A. and Fanali, S., 2004. Reversedphase capillary electrochromatography for the simultaneous determination of acetylsalicylic acid, paracetamol, and caffeine in analgesic tablets. Electrophoresis. 25 (4-5): 615-621.

19. Criado, A., Cardenas, S., Gallego, M. and Valcarcel, M., 2000. Fast urinary screening for paracetamol using on-line microwave assisted hydrolysis and spectrophotometric detection. Analyst. 125 (6): 11791183

20. Abbas, A., Nahid, S. and Ali, R. Z., 2006. Spectrophotometric determination of salicylamide and paracetamol in biological samples and pharmaceutical formulations by a differential kinetic method. Acta Chim. Slov. 53: 357-362.

21. Belal, S. F., Elsayed, M. A., Elwalily, A. and Abdine, H., 1979. Spectrophotometric determination of acetaminophen and salicylamide through nitrosation and subsequent chelation. Analyst. 104 (1243): 919-927. 
22. Miller, J. N. and Miller, J. C., 2000. 4th ed., Statistics and Chemometrics for Analytical Chemistry. Pearson Education Limited, London, pp. 271

23. British Pharmacopoeia on CDROM. 2001. 3rd ed., The Stationery Office Ltd., London.

24. Elkheir, A. A., Belal, S., Elsadek, M. and Elshanwani, A., 1986. Spectrophotometric determination of acetaminophen, oxyphenbutazone and salicylamide by nitration and subsequent complexation reactions. Analyst. 111 (3): 319-321.

25. Sultan, S. M., Alzamil, I. Z., Arahman, A. M. A., Altamrah, S. A. and Asha, Y., 1986. Use of cerium(IV) sulphate in the spectrophotometric determination of paracetamol in pharmaceuticals preparations. Analyst. 111 (8): 919921.
26. Morelli,B.,1989. pectrophotometric determination of paracetamol in pure form and in tablets. J. Pharm. Biomed. Anal. 7 (5): 577-584.

27. Nagaraja, P., Murthy, K. C. S. and Rangappa, K. S., 1998. Spectrophotometric method for the determination of paracetamol and phenacetin. J. Pharm. Biomed. Anal. 17 (3): 501-506.

28. Al-Abachi, M. Q and Al-Ward, H. S., 2001. Spectrophotometric micro determination of paracetamol in pharmaceutical preparations via oxidative coupling with o-cresol and sodium periodate. National $\mathrm{J}$. Chem. 4: 538-548.

29. Knochen, M. Giglio, J. and Reis, B. F., 2003. Flow-injection spectrophotometric determination of paracetamol in tablets and oral solutions. J. Pharm. Biomed. Anal. 33 (2): 191-197.

$$
\begin{aligned}
& \text { التقدير الطيفي للباراسيتامول في المستحضرات الصيدلانية باستعمال ملح } \\
& \text { النتروزو-R كاثف طيفي حساس المان } \\
& \text { سديم صبحي عبل* } \\
& \text { رغد سنان عبل الستارث* } \\
& \text { *قمم الكبمباء، كلية العلوم، جامعة بغداد، بغداد ـ العراق }
\end{aligned}
$$$$
\text { الكلمات المفتاحية: باراسيتامول، التقدير الطيفي، ملح النتروزو-R، المستحضرات الصيدلانية. }
$$

يتضمن البحث تطوير طريقة طيفية حساسة لتقدير البار اسيتامول في المحلول المائي باستعمال كاثف طيفي

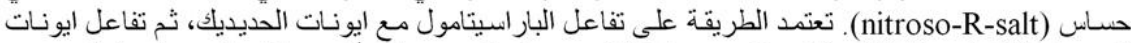

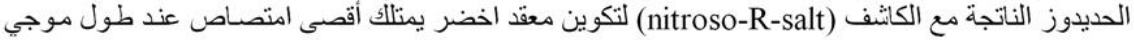

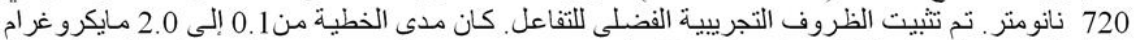

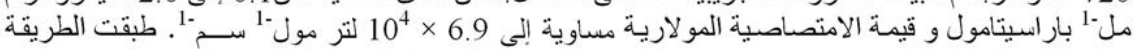

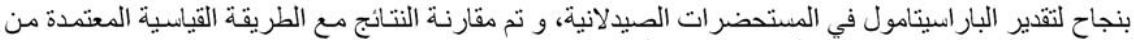

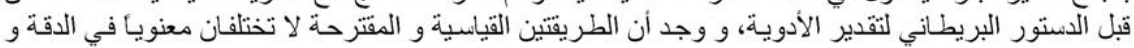

